NBER WORKING PAPER SERIES

THE WTO GOVERNMENT PROCUREMENT AGREEMENT AND ITS IMPACTS ON TRADE

\author{
Hejing Chen \\ John Whalley \\ Working Paper 17365 \\ http://www.nber.org/papers/w17365
}
NATIONAL BUREAU OF ECONOMIC RESEARCH
1050 Massachusetts Avenue
Cambridge, MA 02138

August 2011

We are grateful to the Ontario Research Fund for financial support, and to Gilbert Mao for comments. The views expressed herein are those of the authors and do not necessarily reflect the views of the National Bureau of Economic Research.

NBER working papers are circulated for discussion and comment purposes. They have not been peerreviewed or been subject to the review by the NBER Board of Directors that accompanies official NBER publications.

(C) 2011 by Hejing Chen and John Whalley. All rights reserved. Short sections of text, not to exceed two paragraphs, may be quoted without explicit permission provided that full credit, including $\odot$ notice, is given to the source. 
The WTO Government Procurement Agreement and Its Impacts on Trade

Hejing Chen and John Whalley

NBER Working Paper No. 17365

August 2011

JEL No. F0,F1,F13

\begin{abstract}
$\underline{\text { ABSTRACT }}$
This paper assesses the impacts of the WTO Government Procurement Agreement (GPA) on trade in both goods and services among members using a gravity model applied to a panel dataset covering 20 OECD countries over the period 1996-2008 for trade in goods and 1999-2008 for trade in services. The agreement dates from 1996 and covers 41 (mainly OECD) countries (/areas). China is now negotiating possible membership. Little has been written on the GPA which is a plurilateral agreement covering both goods and services. It mutually extends commitments only to signatories, but has commitments going beyond those in the earlier GATT procurement code. Government service markets are large, and trade in these also has spillover effects on trade in services and goods.

Results suggest that GPA membership has a positive impact on trade in both goods and services between parties as well as on outward foreign affiliate service sales. The number of GPA parties has a small marginal negative effect on trade in goods. Service exports also increase slightly with more parties participating in the GPA. The growth of government procurement contracts above the threshold under the GPA also fosters service imports, exports and outward foreign affiliate sales.
\end{abstract}

\author{
Hejing Chen \\ Department of International Economics and Business \\ School of Economics \\ Xiamen University \\ 361005 Fujian Province \\ P.R.China \\ hjchen.xmu@gmail.com \\ John Whalley \\ Department of Economics \\ Social Science Centre \\ University of Western Ontario \\ London, ON N6A 5C2 \\ CANADA \\ and NBER \\ jwhalley@uwo.ca
}




\section{The WTO Government Procurement Agreement and Its impacts on Trade}

\section{INTRODUCTION}

Governments at central and sub-central levels as well as other public entities play an important role in world trade. But it was not until the Tokyo Round that efforts began to bring government procurement under international trade rules. The belief was that discriminatory government procurement practices were a significant non-tariff barrier and retarded the growth of world trade. Under the GATT Government Procurement Agreement signed in 1979 (GATT GPA 1979), government procurement entities were obliged to follow core multilateral trade rules, i.e. non-discrimination and transparency rules. But since the conclusion of the Uruguay Round in 1994, ongoing negotiated procurement liberalization has been focused on the WTO Government Procurement Agreement (WTO GPA 1994). It is not a condition of WTO membership that countries join the GPA, since the GPA superseded the 1994 single undertaking when the WTO evolved from the GATT. The agreement is a plurilateral agreement only involving signatories and embodies deeper commitments than the GATT GPA 1979 both in terms of itemized coverage and thresholds for competitive bidding. It began in 1996 as an arrangement to which 21 countries initially committed themselves, including US, Japan and the EU; Other countries have subsequentially joined, and currently around 41 countries are parties to the agreement. As with other trade agreements, with non-discriminatory and transparency among parties as key rules, parties are entitled to impartial (thus enhanced) access rights to foreign member markets, but simultaneously agree to grant those rights to other member countries. 
Despite its potential significance for world trade, there are few papers which empirically evaluate its impacts on trade flows, and especially on trade in services. We evaluate its impacts in ways which take advantage of the sequential addition of countries to GPA membership. We first outline the evolution of the GPA and also highlight the gap between its nominal and real coverage. We use data on notifications to the WTO GPA committee of procurement contract awards under the GPA over time to assess the government procurement market size for the main GPA parties. We then use a gravity model to estimate the GPA's impacts on trade flows using the panel data for 20 OECD countries from 1996 to 2008.

Our results show that the WTO GPA has had a positive influence on inter-OECD trade in goods and services as well as on outward foreign affiliate service sales. Simple data analysis of contracts awarded under the GPA overestimates the extent of trade and impacts of the GPA since not all GPA covered international transactions would not have occurred without the GPA. Hence our use of a gravity model. Additional, restrictions in GPA articles and regulations also imply that enhanced market access by foreign suppliers will not be automatically achieved through membership of the GPA. 


\section{The Origins of the WTO Government Procurement Agreement}

\subsection{The GPA from 1979 to 2010}

Buy national policies in government purchasing (government procurement) were omitted from the original GATT in Article III "National Treatment on Internal Taxation and Regulation" and Article XVII "State Trading Enterprises" in 1947. The first GATT Agreement on Government Procurement (GATT GPA) was signed only in 1979 and entered into force in 1981. It contained obligations of non-discrimination (national treatment and most-favored-nation treatment (MFN)) and transparency rules for procurement of goods by central government entities of its signatories, and a purchasing contract threshold set at SDR 150,000.

In 1987, the GATT GPA 1979 was amended by adding a limited number of services (such as construction services), reducing the threshold for contracts involving goods for central government entities to SDR 130,000 and setting the threshold for construction contracts at a higher level of SDR 5,000,000. The amended GATT GPA entered into force in 1988.

But during the Uruguay Round, parties to the Agreement also held negotiations trying to extend the scope and coverage of the Agreement to sub-central government and quasi-governmental bodies, and also to services and construction services as well as incorporating a bid-challenge system. As a result, a new GPA (WTO GPA) was signed at the end of the Uruguay Round in 1994, and entered into force on 1 January 1996. A new revised text was agreed in December2006 and updated in December 2010.

Table 1 summarizes the evolution of these Agreements. This history embodies two major milestones. One was the introduction of GATT GPA in 1979 which brought government procurement under GATT. The other was the WTO GPA of 1994 which broadened the coverage of 
the GPA under WTO.

Table 1 The Evolution of GATT and WTO Agreements on Government Procurement

\begin{tabular}{|c|c|}
\hline Date & GPA Version \\
\hline 1947 & Government procurement excluded under GATT Article III: 8 and XVII:2 \\
\hline April 1979 & GPA 1979 signed \\
\hline J anuary 1981 & GPA 1979 enters into force \\
\hline November 1983 & Negotiations based on Article IX:6(b) of GPA 1979 commence \\
\hline November 1986 & $\begin{array}{l}\text { Protocol to the Agreement include amendments to Articles I, II, IV, V } \\
\text { and VI of GPA } 1979\end{array}$ \\
\hline J anuary 1988 & Amended GPA 79 enters into force \\
\hline April 1994 & GPA 1994 signed in Marrakesh \\
\hline J anuary 1996 & GPA 1994 enters into force \\
\hline $\begin{array}{l}\text { February } 1997- \\
\text { ongoing }\end{array}$ & Preparatory work for negotiations under Article XXIV: 7 of GPA 1994 \\
\hline December 2006 & Provisionally agreed revised GPA text (GPA/ W/ 297) \\
\hline December 2010 & Provisionally agreed revised GPA text (GPA/ W/ 313) \\
\hline
\end{tabular}

Source: WTO, http://www.wto.org/english/tratop_e/gproc_e/overview_e.htm

\subsection{GPA Parties and Observers}

As a plurilateral agreement, the WTO GPA (hereafter GPA) only regulates government procurement practices on a voluntary basis of those WTO members who choose to bind in the GPA. The GPA itself has no enforcement mechanism for commitments going beyond WTO obligations. So far, the membership of GPA is still limited. Most of the 41 parties $^{1}$ are developed countries (areas) and NICs ${ }^{2}$, while the majority of developing countries have not joined. There are also 27 observers $^{3}$ in the GPA Committee who approve accession to the GPA. 9

\footnotetext{
${ }^{1}$ Current GPA members (with effect from 1 January 2010) include Canada, European Communities (including its 27 member States: Austria, Belgium, Bulgaria, Cyprus, Czech Republic, Denmark, Estonia, Finland, France, Germany, Greece, Hungary, Ireland, Italy, Latvia, Lithuania, Luxemburg, Malta, Netherlands, Poland, Portugal, Romania, Slovak Republic, Slovenia, Spain, Sweden, and United Kingdom), Hong Kong China, Iceland, Israel, Japan, Korea, Liechtenstein, Netherlands with respect to Aruba, Norway, Singapore, Switzerland, Chinese Taipei, United States.

${ }^{2}$ Korea, Singapore, Hong Kong and Israel participated in the Uruguay Round as developing countries, however, they are so called new industrialized countries not typical developing countries.

${ }^{3}$ Current GPA observers(with effect from 1 July 2010) include 23 countries and 4 international intergovernmental organizations, among which Albania, Armenia, China, Georgia, Jordan, Kyrgyz Republic, Moldova, Oman, Panama are undergoing acceding negotiation.
} 
countries are currently in ongoing negotiation for accession.

The smaller number of GPA members than of the WTO reflects the reluctance of most developing countries to join the GPA. Current GPA members have frequently tried to persuade countries seeking to join the WTO (especially those with a large state sector) to commit to joining the GPA upon WTO accession, although GPA membership is not a prerequisite for WTO accession (Wang, 2007).

Table 2 lists the entry date of GPA parties and observers. EU members make up more than half of the parties, and the rest are in North America and Asia. All 27 observers are developing countries in Asia, South America and Africa, except Australia and New Zealand, which are OECD members in Oceania. Among observers who have started negotiating accession, China is the prime concern of the current GPA parties; not only because of its high growth rate and large size of its economy, but also due to the historically dominant role and large size of different level of governments.

Table 2 Entry and Acceptance Date of GPA Parties and Observers

\begin{tabular}{|c|c|c|c|}
\hline Parties & $\begin{array}{c}\text { Date of entry } \\
\text { into } \\
\text { force/accession } \\
\text { (dd/mm/yyyy) }\end{array}$ & $\begin{array}{c}\text { Observer } \\
\text { government }\end{array}$ & $\begin{array}{c}\text { Date of } \\
\text { acceptance by } \\
\text { committee as } \\
\text { observers } \\
\text { (dd/mm/yyyy) }\end{array}$ \\
\hline $\begin{array}{l}\text { Canada, United States, J apan, Norway, } \\
\text { Switzerland, Israel }\end{array}$ & \multirow[t]{4}{*}{ 01/ 01/ 1996} & Albania * & $02 / 10 / 2001$ \\
\hline European Communities with regard to its & & Argentina & 24/02/ 1997 \\
\hline 27 member States: & & Armenia * & $16 / 07 / 2004$ \\
\hline & & Australia & 04/ 06/ 1996 \\
\hline Austria, Belgium, Denmark, & \multirow[t]{5}{*}{ 01/ 01/ 1996} & Bahrain & $09 / 12 / 2008$ \\
\hline Finland, France, Germany, Greece, & & Cameroon & $03 / 05 / 2001$ \\
\hline Ireland, Italy, Luxemburg, the & & Chile & 29/09/1997 \\
\hline Netherlands, Portugal, Spain, & & China * & $21 / 02 / 2002$ \\
\hline Sweden and the United Kingdom & & Colombia & $27 / 02 / 1996$ \\
\hline
\end{tabular}




\begin{tabular}{|c|c|c|c|}
\hline Cyprus, Czech Republic, Estonia, & $01 / 05 / 2004$ & Croatia & 05/ 10/1999 \\
\hline Hungary, Latvia, Lithuania, Malta, & & Georgia * & $05 / 10 / 1999$ \\
\hline Poland, Slovak Republic and & & India & $10 / 02 / 2010$ \\
\hline Slovenia & & J ordan * & $08 / 03 / 2000$ \\
\hline Bulgaria and Romania & $01 / 01 / 2007$ & Kyrgyz Republic* & $05 / 10 / 1999$ \\
\hline Hong Kong , China & 19/ 06/ 1997 & Moldova * & $29 / 09 / 2000$ \\
\hline Iceland & $28 / 04 / 2001$ & Mongolia & 23/ 02/1999 \\
\hline Korea & 01/ 01/ 1997 & New Zealand & $09 / 12 / 2008$ \\
\hline Liechtenstein & 18/ 09/ 1997 & Oman * & $03 / 05 / 2001$ \\
\hline the Netherlands with respect to Aruba & $25 / 10 / 1996$ & Panama * & 29/ 09/ 1997 \\
\hline Singapore & 20/ 10/ 1997 & Saudi Arabia & $13 / 12 / 2007$ \\
\hline \multirow[t]{3}{*}{ Chinese Taipei } & $15 / 07 / 2009$ & Sri Lanka & $23 / 04 / 2003$ \\
\hline & & Turkey & 04/ 06/ 1996 \\
\hline & & Ukraine & $25 / 02 / 2009$ \\
\hline
\end{tabular}

Note: * means the observer is undergoing negotiating accession

Source: WTO, http://www.wto.org/english/tratop e/gproc e/memobs e.htm

2.3 The difference between the GPA's nominal and real coverage

The impact of GPA membership on its members' trade is qualified in various ways since the effective coverage of commitment to the GPA is ambiguous due to a four step procedure of accession negotiations covering membership, entity coverage, product coverage and threshold. Countries have to first choose whether to join the GPA when they become WTO members. After the accession procedure to the GPA starts, observers can then determine which entities are bound under their GPA commitments. Under the Annex 1 to3 of Appendix I of the GPA, each party notifies lists of central level government, sub-central government and other public entities covered. Only those entities in the list undertake GPA commitments. For example, many parties exclude the department of defense from their central government list.

Product coverage is also typically selective for GPA members. As a general rule, all goods are covered by the GPA, while Annexes 4 and 5 to Appendix I specify each Party's covered services 
and construction services ${ }^{4}$. Services deemed sensitive, for instance dredging, transportation, R\&D, and printing services, are often excluded from GPA parties’ Annex 4. Finally, the threshold value above which the public procurement contract is obliged to follow GPA rules can provide a fourth element of weakened coverage. For each party of the GPA, there are 9 (3 times 3) thresholds to be determined for three categories of products (goods, services and construction services) and entities (central government, sub-central government and other entities); though generally there are ranges set for thresholds.

Table 3 reports the GPA threshold commitments of the EU, Japan and USA. These thresholds differ among the three categories, with a much higher threshold for construction services. Due to different financial regimes across countries, the thresholds for three types of entities vary among members, while sub-central government and other social entities apply higher thresholds than central government entities.

Table 3 Threshold Commitment of Main GPA Parties unit: thousand SDRs

\begin{tabular}{|c|c|c|c|c|c|c|c|c|c|}
\hline \multirow[t]{2}{*}{ COUNTRY } & \multicolumn{3}{|c|}{ ANNEX 1} & \multicolumn{3}{|c|}{ ANNEX 2} & \multicolumn{3}{|c|}{ ANNEX 3} \\
\hline & Goods & \begin{tabular}{|l|} 
Services \\
except \\
construction \\
services
\end{tabular} & $\begin{array}{l}\text { Construction } \\
\text { services }\end{array}$ & Goods & \begin{tabular}{|l|} 
Services \\
except \\
construction \\
services
\end{tabular} & $\begin{array}{l}\text { Construction } \\
\text { services }\end{array}$ & Goods & $\begin{array}{l}\text { Services } \\
\text { except } \\
\text { construction } \\
\text { services }\end{array}$ & $\begin{array}{l}\text { Construction } \\
\text { services }\end{array}$ \\
\hline $\begin{array}{l}\text { EU } \\
\text { members }\end{array}$ & 130 & 130 & 5,000 & 200 & 200 & 5,000 & 400 & 400 & 5,000 \\
\hline Japan & 130 & 130 & $\begin{array}{l}4,500 \\
\text { Architectural } \\
\text { services: } \\
450\end{array}$ & 200 & 200 & $\begin{array}{l}15,000 \\
\text { Architectural } \\
\text { services: } 1,500\end{array}$ & 130 & 130 & $\begin{array}{l}4,500 \text { or } 15,000 \\
\text { Architectural } \\
\text { services: } \\
450\end{array}$ \\
\hline $\begin{array}{l}\text { United } \\
\text { States }\end{array}$ & 130 & 130 & 5,000 & 355 & 355 & 5,000 & $\begin{array}{l}250,000 \\
(U S D) \text { or } \\
400,000 \\
\text { SDRs }\end{array}$ & $\begin{array}{l}250,000 \\
\text { (USD) } \\
400,000 \\
\text { SDRS }\end{array}$ & 5,000 \\
\hline
\end{tabular}

Source: WTO, http://www.wto.org/english/tratop_e/gproc_e/thresh_e.htm

\footnotetext{
4 The newly provisionally agreed revised GPA text 2010 differ from preceding version in one way that one new Annex is added to list the goods covered by each party, therefore the coverage of goods becomes selective, and there are altogether 7 Annexes in Appendix I, with Annex 1 to 3 for entity list, Annex 4 to 6 for product list, and Annex 7 as General Notes.
} 
The GPA text (article XV in the GPA 1994, article III and XIII in the GPA 2006 and 2010) also provides exceptions to its general nondiscriminatory rules and open or selective tendering procedures which can also potentially provide extra coverage for own country preferential government procurement activities. Although negotiations on government procurement in the Tokyo and Uruguay Round achieved substantial expansion of coverage by extending rules to the procurement of goods and services (including construction services) by national and sub-central level government as well as public entities, the selection of membership, entity coverage, product coverage and threshold along with the exception option for nondiscriminatory and transparency rules once again make the GPA's real coverage unclear. 


\section{The government procurement market under the GPA}

3.1 The government procurement market for main GPA parties

\subsubsection{Market size}

A critical element in assessing the impact of the GPA on inter-party trade flows is the size of the GPA covered procurement market. There are two different methods for calculating the size of the government procurement market for GPA countries, reflecting two different sources of available data. One uses the SNA (System of National Accounts) to estimate the size of the government procurement market based on government receipts and payments. This method yields an upper based in estimate of the possible scale of government procurement since not all government expenditure other than compensation of employees and defense can be treated as government procurement. EC(1997,1998), Francois et al.(1996), Trionfetti (2000) and OECD (2001) use this method using the 1968 version of the SNA to yield consistent data across countries.

The other method uses a bottom-up approach based directly on data on procurement expenditure by national entities responsible for procurement decisions and forming their WTO notifications. This approach yields a direct estimate of the size of government procurement market since government procurement values are based on a contract by contract basis. It is however not ideal because of a lack of consistency across countries subject in notification requirements. The data source for this bottom-up method is annual data submit by the GPA parties to the WTO on their procurement covered by the GPA; and periodic surveys of the Tenders Electronic Daily (TED) and notices published in the Official Journal of European Union (OJEU) with respect to the requirement of the EU members (through EU Directives) to publish procurement tender and contract award notices 
Table 4 reports literature estimates of the size of procurement markets using both SNA-based and bottom-up approaches. The estimates for the ratio of public procurement to GDP lie in a wide range between $0.42 \%$ to $19.96 \%$, illustrating the disparity among studies. Using a bottom-up approach, our estimates on a aggregate basis are similar to those of EC (2000), while the estimate on an above threshold basis is significantly higher than that of Hoekman (1997) which only takes procurement of goods by central governments into consideration. This difference is, to some extent, a reflection of the evolution of the GPA from the Tokyo Round to the Uruguay Round.

Table 4 Estimates of the size of government procurement markets

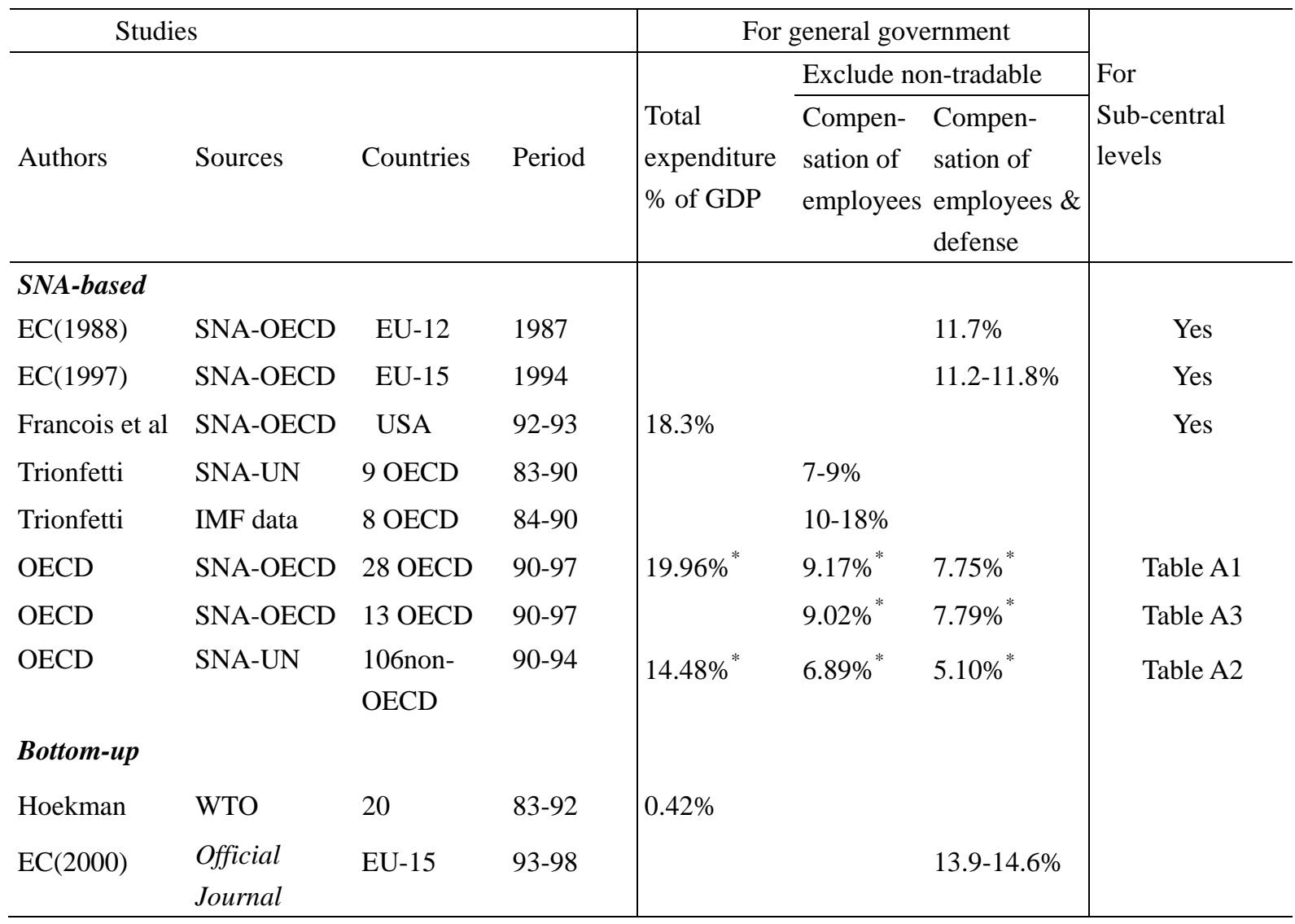

Note: *= weighted average; In the reported EC studies, the ratios measure public procurement.

Source: OECD (2001)

Figure 1 displays EU government procurement to GDP as a proportion of GDP, as an example of a large region situation, with added detail among above threshold and aggregate (above and 
below threshold). In the figure the ratio of the government procurement to GDP is roughly constant over time, and government procurement above threshold is only one-tenth to one-fifth of aggregate procurement, suggesting space and opportunity for the GPA to play a role in the future. There is a trend of growth in the absolute value of government procurement on either basis of above threshold or aggregate.

Figure 1 Estimates of the size of the EU government procurement market:

1996-2008

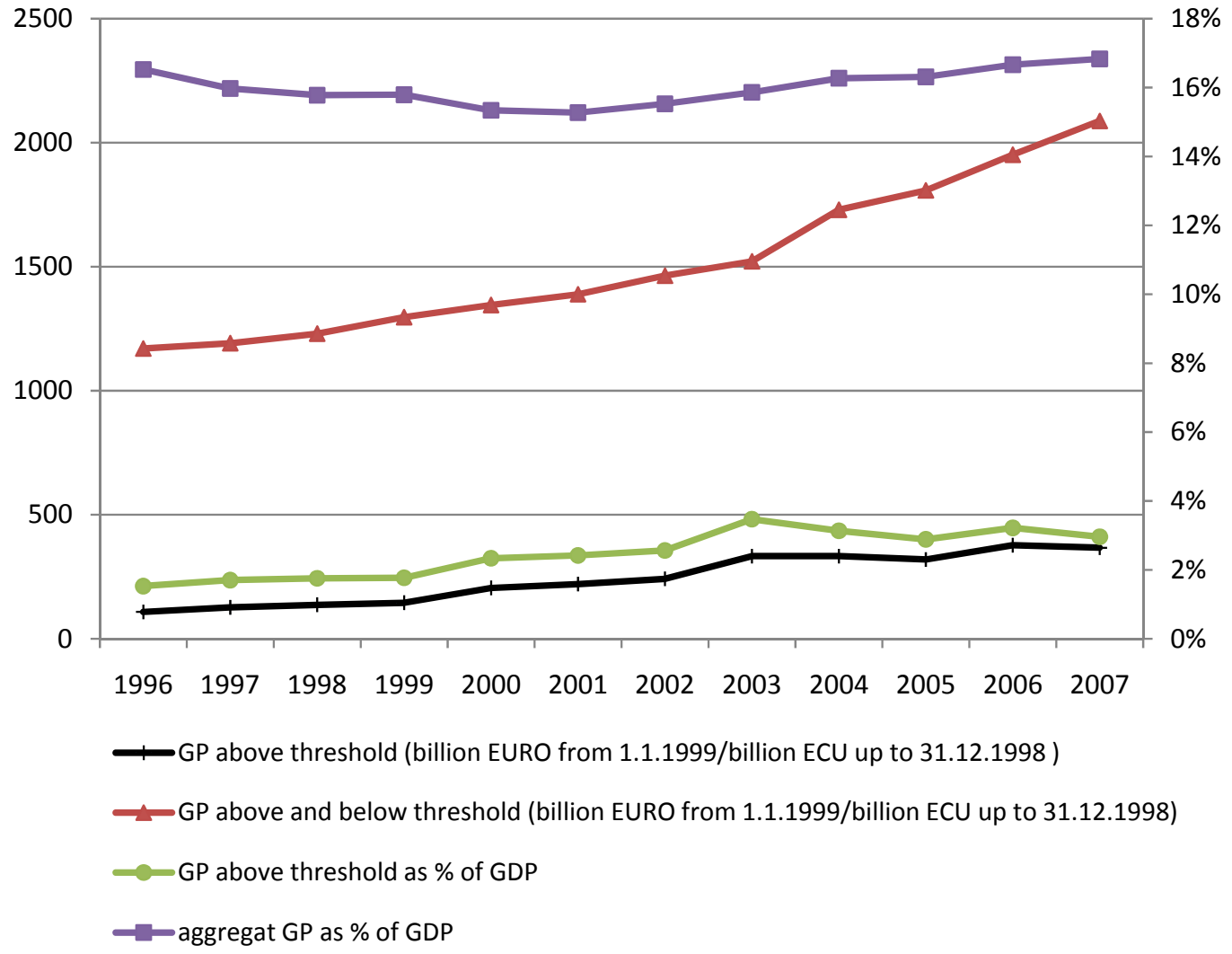

Note: EU (15 members, EU Institutions excluded) 1996-2003

EU (25 members, EU Institutions excluded) 2004-2006

EU (27 members, EU Institutions excluded) 2007

GP means Government Procurement

Source: World Bank Indicators, European Central Bank statistic data warehouse, EU's GPA notification to the WTO. 
US notifications to the WTO on government procurement under the GPA are not as detailed as those for the EU, and data on government procurement below threshold are available only at federal government level. Table 5 reports estimates of the size of government procurement markets in the US and the ratio to GDP. The proportion of the US federal government procurement above threshold is high, amounting to more than $90 \%$ of total procurement for Annex 1 commitments. Also, the absolute value of government procurement in the US increases nearly three times from 1996 to 2008, while the ratio to GDP ranges from 5-9\%.

Table 5 Estimates of the size of the US government procurement market: 1996-2008 Unit: billion US\$

\begin{tabular}{l|c|c|c|c|c}
\hline Year & $\begin{array}{c}\text { Annex 1 } \\
\text { above } \\
\text { threshold }\end{array}$ & $\begin{array}{c}\text { Annex 1 } \\
\text { below } \\
\text { threshold }\end{array}$ & $\begin{array}{c}\text { Total } \\
\text { Government } \\
\text { Procurement }\end{array}$ & $\begin{array}{c}\text { GDP } \\
\text { (current price) }\end{array}$ & $\begin{array}{c}\text { Total government } \\
\text { Procurement as \% of } \\
\text { GDP }\end{array}$ \\
\hline 1996 & 216.130 & 9.101 & 485.900 & 7783.9 & 6.24 \\
1997 & 195.742 & 9.671 & 477.871 & 8278.9 & 5.77 \\
1998 & 197.899 & 9.286 & 496.531 & 8741 & 5.68 \\
1999 & 205.408 & 9.857 & 525.675 & 9301 & 5.65 \\
2000 & 63.503 & 5.692 & 414.226 & 9898.8 & 5.18 \\
2001 & 133.268 & 4.638 & 528.632 & 10233.9 & 5.17 \\
2002 & 180.878 & 5.146 & 610.245 & 10590.2 & 5.76 \\
2003 & 320.834 & 5.809 & 767.006 & 11089.2 & 6.92 \\
2004 & 250.677 & 5.956 & 722.179 & 11812.3 & 6.11 \\
2005 & 380.502 & 9.519 & 890.221 & 12579.7 & 7.08 \\
2006 & 431.328 & 7.122 & 964.041 & 13336.2 & 7.38 \\
2007 & 760.510 & 7.328 & 1316.993 & 14061.8 & 9.37 \\
2008 & 384.945 & 8.082 & 1150.161 & 14369.1 & 8.00 \\
\hline
\end{tabular}

Note: *total government procurement is added up across the contract awards of entities in Annex1 (both above and below threshold), Annex 2 and Annex 3.

Source: GDP data are from World Development Indicators, World Bank, 2010. Data on the government procurement are calculated by the authors using US’ GPA notification to the WTO.

Based on these estimates of the size of government procurement markets in the EU and the US, if government procurement below threshold is excluded, government procurement markets 
covered by the GPA are about 3\% of GDP for the EU and 7-8\% for the US. These estimates are lower than most earlier OECD studies based on SNA data source.

3.2 The composition of government procurement markets under the GPA for the main GPA parties

\subsubsection{By entity}

The central, sub-central government and other entities are the three categories covered by the GPA, and their relative importance in the government procurement market varies between different countries. However, with thresholds set for most parties of the GPA, the threshold for Annex 3 (other entities) is generally higher than that for Annex 1, and also sometimes Annex 2. The entity composition for EU and US government procurement markets reflect threshold levels for different entities (See Figure 2 and Figure 3). In the EU government procurement market under the GPA ${ }^{5}$, other entities with the highest threshold are the smallest portion. These relative share account for about $10-15 \%$, while the sub-central government is the largest with a $50 \%$ share.

The share for the central government is nearly $30-35 \%$.

Figure 2 Entity composition of the EU government procurement market under the GPA: 1996-2008

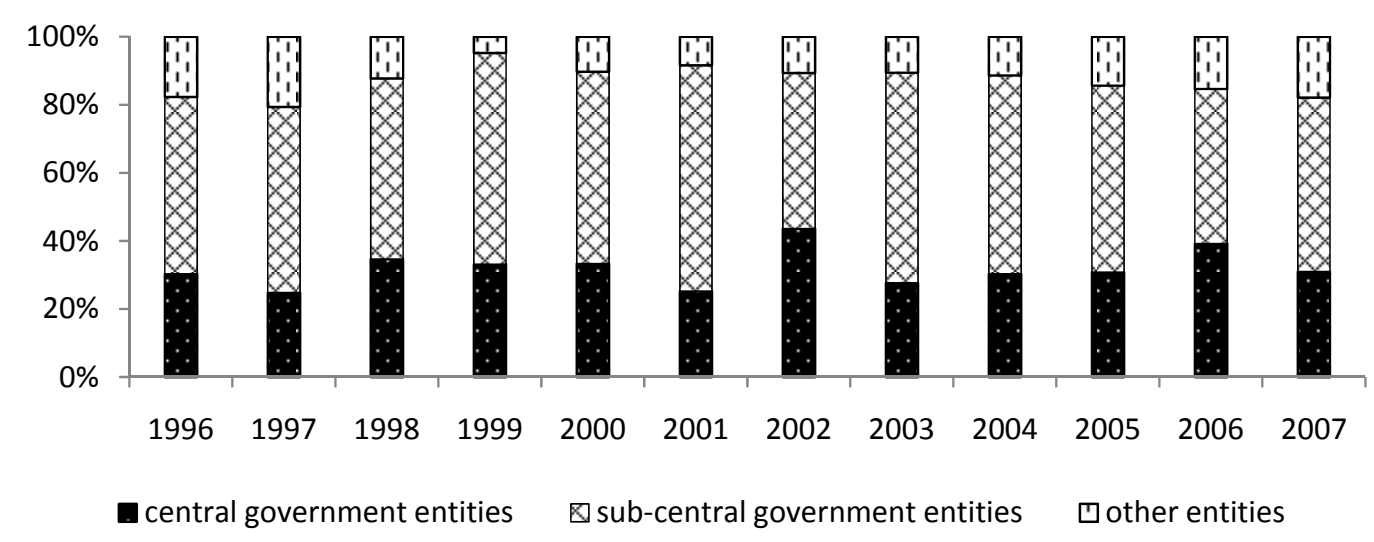

\footnotetext{
${ }^{5}$ The government procurement market under the GPA means that only those contracts belonging to product list in Annex 4 to 6 with awards above threshold for the entities in Annex 1 to 3 are considered.
} 
Source : Calculated by the authors using data on EU GPA notifications to the WTO.

As with the US case, the relative ranking across the three categories are the same as for the EU, except that the share for Annex 3 is minor. The share for central governments is roughly $40 \%$.

Figure 3 Entity composition of the US government procurement market under the GPA: 1996-2008

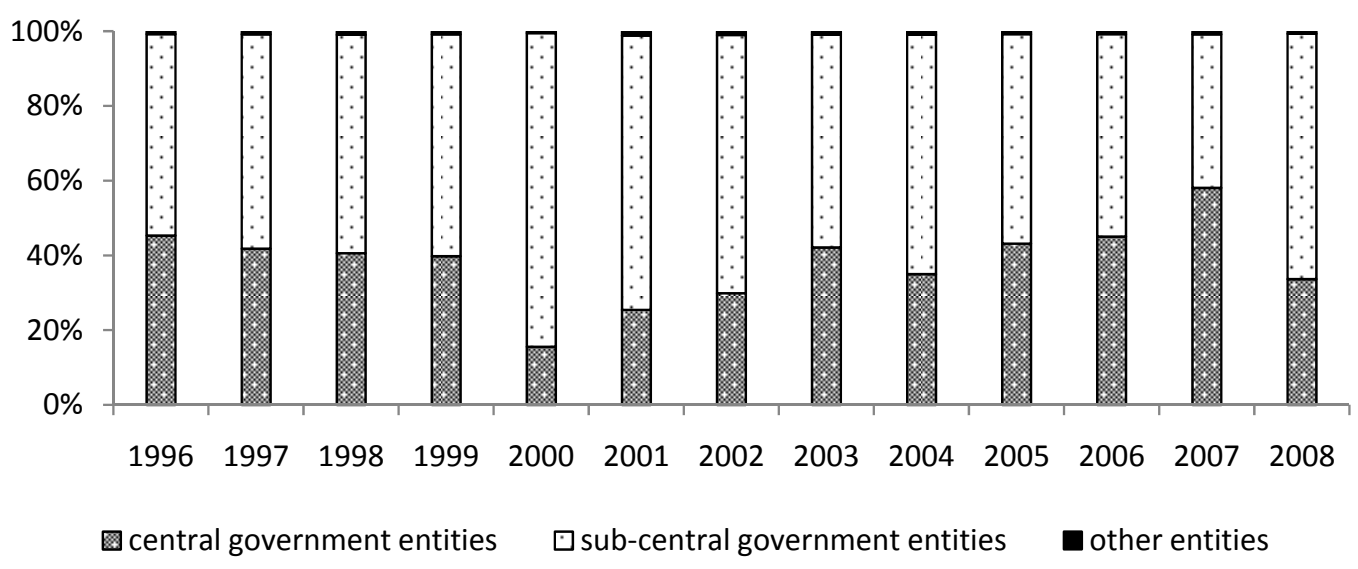

Source : Calculated by the authors using data on US GPA notifications to the WTO.

\subsubsection{By product}

Products covered by the GPA are divided into two categories, goods and services. When we analyze the product composition of the government procurement market under the GPA, we include construction services in the services category. Within the two major categories, services occupy the dominate position, with $60-65 \%$ of government procurement above threshold. This is the case for the EU, US and Japan. According to the WTO Universal List of Services in WTO document code of MTN.GNS/W/120, construction services belong to the services category. In the GPA, the threshold for construction service is individually listed. This is because construction services purchased by governments and other entities (especially state-owned enterprises) are often connected to other infrastructure construction with large contracts.

\subsubsection{By origin of suppliers}


Under GPA Article III, the principles of non-discrimination apply to both foreign affiliates and ownership (Article III:2(a)) and country of origin (Article III:2(b)) ${ }^{6}$. This means that foreign suppliers can compete against domestic suppliers and meet procurement bids either through cross-border supply or foreign affiliation sales. Based on the notifications of GPA parties, government procurement markets seem far from being internationally integrated. Figure 4 shows the relative shares of Japan's government procurement above threshold for goods and services by domestic suppliers and foreign suppliers. Even compared with the low share of procurement for goods by non-Japan suppliers, the situation of market access is even lower in the service sector,

which suggests a strong home bias in government procurement markets.

Figure4 Origin composition of Japan's Government Procurement on Goods and services under the GPA:1997-2008 unit: billion SDR

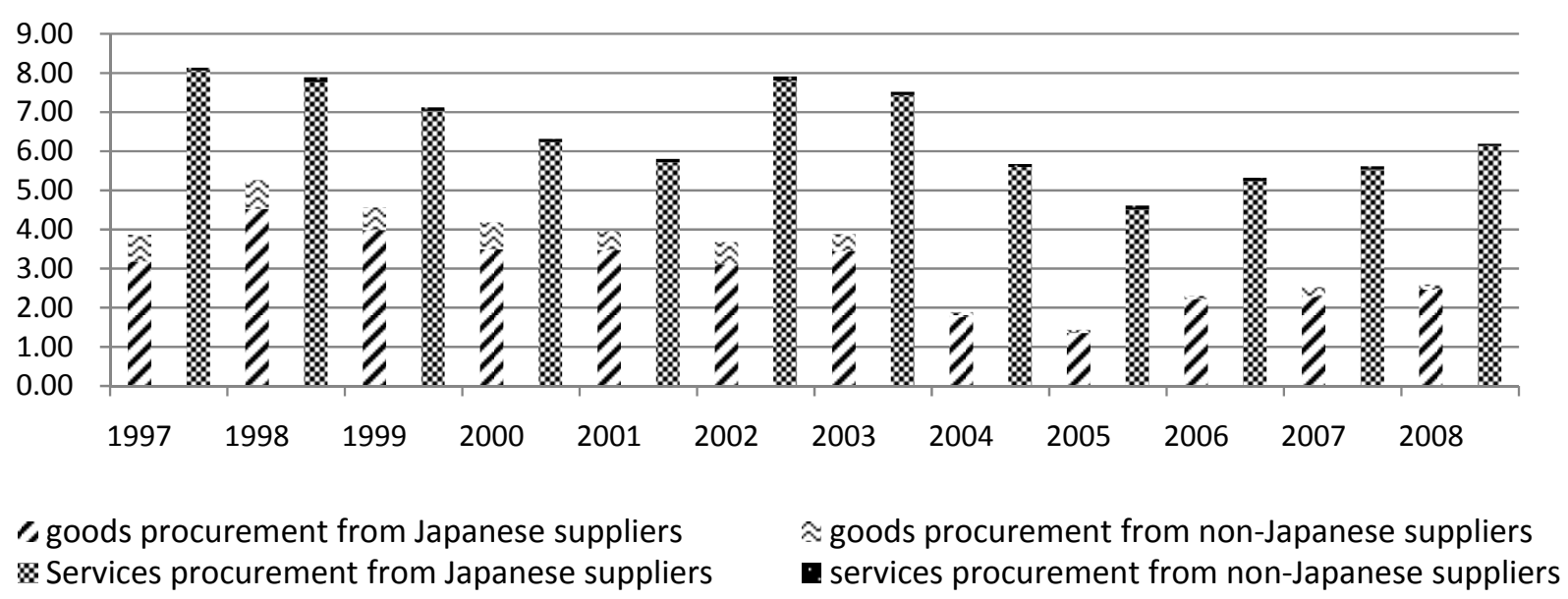

Source: Calculated by the authors using data on Japan's GPA notifications to the WTO

${ }^{6}$ In GPA 2006 and 2010 version, these regulation are in Article V:2(a)(b) and Article IV:2(a)(b), respectively. 


\section{Assess the impact of the GPA using a gravity model}

The gravity model has been widely applied in empirical trade analysis, following Tinbergen (1962) and Pöyhönen(1963). More recent developments (e.g. Anderson,1979; Helpman and Krugman, 1985; Deardorff ,1995; Feenstra et al., 2001; Eaton and Kortum, 2002; Anderson and Wincoop, 2003) also support the use of gravity models from a trade theoretic view point. Gravity models have previously been used to analyze the impact of barriers to services trade by comparing predicted and actual levels of services trade flows (see Francois,2001; Park, 2002; Grunfeld and Moxnes, 2003; etc ) and to compare differences in determinants of trade in services and goods (see Kimura and Lee, 2006; Lennon, 2006). Here we use a standard gravity model augmented with GPA variables to assess the GPA's impact on bilateral trade flows in both goods and services among GPA parties.

Academic research on the impact of government procurement on international trade flows started in the 1970s. Baldwin (1970) argued that discriminatory procurement policy may have inconsequential impacts on trade flows under assumptions of perfect substitution between domestic and foreign products, a relative small size of government procurement and unique market price for private and public demand. His proposition was further examined by Mattoo (1996). McAfee \& McMillan (1989), Trionfetti (2000), Evenett \& Hoekman (2004, 2005) analyze the welfare effect of different discriminatory form of government procurement practices. Empirical studies including Baldwin and Richardson (1972) and Trionfetti (2001) show that the discriminatory government procurement exists and has a negative impact on import.

4.1 Empirical specifications and data

A standard gravity model takes the following form: 


$$
L n T_{i j}=\beta_{0}+\beta_{1} L n G D P_{i}+\beta_{2} L n G D P_{j}+\beta_{3} L n D I S T_{i j}+E_{i j}
$$

where $T_{i j}=$ bilateral trade flows (exports or /and imports) between country $\mathrm{i}$ and country $\mathrm{j}$, $\mathrm{GDP}_{\mathrm{i}}=$ economic mass of country $\mathrm{i}, \mathrm{GDP}_{\mathrm{j}}=$ economic mass of country $\mathrm{j}, \quad$ DISTij = geographical distance between the capitals of country i and country $\mathrm{j}, \mathrm{E}_{\mathrm{ij}}=$ error term.

In order to capture the impacts of the GPA on bilateral trade in goods and services, we introduce three additional variables on the right side. One is a dummy variable GPA, which takes the value 1 if the two countries $i$ and $j$ are both members of the GPA. A positive effect on bilateral trade is expected from the dummy variable GPA. The second is NGPA, an interactive variable obtained by multiplying the dummy variable GPA by the total number of GPA parties in year $\mathrm{t}$ ( represented as "gpan” ). We use this interactive variable to capture the effect of the number of GPA partiess on bilateral trade in goods and services. The expected effect of the NGPA on bilateral trade is negative since bilateral trade may be switched to new or other members of the GPA. The third variable is CLNGVI (CLNGVJ), also an interactive variable, obtained by multiplying the dummy variable GPA by the log of an index of government procurement values above threshold (with the government procurement value under GPA in year 2000 equaling 1 in the base period) for country i or country j (represented as “gvii” or “gvij”). The government procurement value above threshold under the GPA by different members is provided in different local currency units, hence, we use this indexing method to control for this influence. This interactive variable captures variation in government procurement values on bilateral trade in goods and services.

A final dummy variables RTA is included to reflect the impact of trading bloc membership. As a plurilateral agreement only applicable to signatories, the GPA is similar to a RTA. We use dummy 
variable RTA to control for the influence of other trade-related arrangements. RTA takes the value 1 if the two countries $\mathrm{i}$ and $\mathrm{j}$ signed a free trade agreement with each other.

In existing gravity model literature, there is no consensus on whether the dependent variable should be exports, imports or total trade flows (i.e. the sum of export and import). We use both exports and imports as dependent variables, since home biased government purchasing will reduce imports while GPA membership will potentially yield enhanced access rights to foreign member markets. Since members simultaneously agree to grant rights to other member countries both exports and imports should increase.

Our estimation equations are

$$
\begin{gathered}
L n I M_{i j t}=\beta_{0}+\beta_{1} L_{n} G D P_{i t}+\beta_{2} L_{n} G D P_{j t}+\beta_{3} L n D I S T_{i j}+\beta_{4} G P A_{i j t} \\
+\beta_{5} N G P A_{t}+\beta_{6} C L N G V I_{t}+\beta_{7} R T A_{i j t}+\gamma_{i}+\gamma_{j}+\delta_{t}+\varepsilon_{i j t} \\
L n E X_{i j t}=\beta_{0}+\beta_{1} L n G D P_{i t}+\beta_{2} L n G D P_{j t}+\beta_{3} L n D I S T_{i j}+\beta_{4} G P A_{i j t} \\
+\beta_{5} N G P A_{t}+\beta_{6} \text { CLNGVJ }_{t}+\beta_{7} R T A_{i j t}+\gamma_{i}+\gamma_{j}+\delta_{t}+\varepsilon_{i j t}
\end{gathered}
$$

where NGPA =GPA*gpan and gpan =the number of GPA parties in year $\mathrm{t} ; \quad$ CLNGVI = GPA*Lngvii and Lngvii = log of index of government procurement value above threshold in country i (with the year 2000 as the base period); CLNGVJ=GPA*Lngvij and Lngvij= log of index of government procurement value above threshold in country j (with the year 2000 as the base period).

Equations (2) and (3) are similar to each other, except that when the dependent variable is imports of country i from country j, only procurement values above threshold for country i matter, while procurement values above threshold of country j affect the opposite trade flow, i.e. export of country i to country j.

\section{2.3 Data and methodology}


The data we use is from OECD statistics on international trade in services, and is available for both service exports and imports, broken down by partner country, and for 20 OECD member countries from the years 1999 to 2008. Data are on a balance-of-payments basis, and mainly reflect GATS supply mode 1 (cross-border supply) and mode 2 (consumption abroad) of trade in services. Supply mode 3(commercial presence) of trade in services is of special importance in competing for government procurement contract for foreign suppliers.

Service imports and exports via foreign affiliates are likely the most affected when countries enter the GPA. Data on bilateral trade in service for foreign affiliate trade in services among OECD members is not directly available. We use inward and outward foreign affiliate turnover data with industry sector division specified within services on the UN international standard industrial classification basis code (ISIC Rev.3) as proxies of service exports and imports via mode 3. To check the robustness of results, we compare results when service exports and imports are on a BOP basis (SE/SI) and service exports and imports are on a FATS basis (FAE/FAI) as dependent variables. For trade in goods, we also compare the impact of the GPA on exports (GE) and imports (GI).

Our data covers 20 OECD members ${ }^{7}$. For trade in goods, the period starts from 1996 and ends in 2008, since the GPA came into effect under the WTO in 1996. For trade in services, the period is 1999 to 2008, since the earliest available data on bilateral services trade released by the OECD starts from 1999.

Bilateral exports and imports data on trade in goods are obtained from the UN COMTRADE database. Bilateral exports and imports data on trade in services (BOP and Foreign Affiliate Sales)

\footnotetext{
7 The full list of countries included in the sample : Australia, Austria, Canada, France, Germany, Hungary, Ireland, Italy, Japan, Korea, Luxembourg, Mexico, Netherlands, New Zealand, Norway, Spain, Sweden, Switzerland, UK, US.
} 
are from OECD Statistics. GDP data are from World Development Indicators, and the distance in kilometers between capitals are from COW database Version 2.0. RTA data are from RTA database of WTO. GPA, NGPAN, CLNGVI/CLNGVJ data are calculated by the authors based on WTO notifications.

We first use an ordinary least squares regression with pooled data, and then use fixed country and time effect regressions using panel data following the arguments of Egger(2000) and Feenstra(2003) that the proper specification of the gravity model in most applications would be one of fixed country and time effects, which reflect both the time-invariant export- and import-country effects and the common business cycle or globalization process over the sample period. The Hausman test also supports using fixed effect rather than random effects models.

\subsection{Results}

Table 7 presents the summary statistics for the variable used in the estimations. Definitions are provided in the text and S.D., Min., Max. and $\mathrm{N}$ denote standard deviation, minimum, maximum and number of observation, respectively. The mean of NGPA, Lngvii and Lngvij are used to calculate the net effect of the dummy variable GPA on bilateral trade flow. In a similar way, the mean of dummy variable GPA is used to calculate the net impact of number of the GPA parties and government procurement valued bounded to the GPA of each member on bilateral trade flow.

Table 7 Summary Statistics

\begin{tabular}{llllll|lllllll}
\hline \multicolumn{5}{c}{ Trade in goods } & & \multicolumn{5}{c}{ Trade in services (BoP and Foreign Affiliate Sales) } \\
\hline Variable & Mean & S. D. & Min & Max & N & Variable & Mean & S. D. & Min & Max & N \\
\hline LnGI & 7.411 & 2.133 & -5.498 & 12.734 & 4820 & LnSI & 6.737 & 1.926 & -0.061 & 10.760 & 2626 \\
LnGE & 7.328 & 2.162 & -2.500 & 12.776 & 4820 & LnSE & 6.814 & 1.872 & 0.000 & 11.051 & 2671 \\
LnGDPi & 13.208 & 1.450 & 9.826 & 16.481 & 4940 & LnFAI & 9.016 & 2.487 & 0.000 & 15.233 & 1124 \\
LnGDPj & 13.208 & 1.450 & 9.826 & 16.481 & 4940 & LnFAE & 9.423 & 2.886 & 0.385 & 17.388 & 706 \\
LnDIST $^{\mathbf{a}}$ & 8.230 & 1.225 & 5.438 & 9.896 & 4940 & LnGDPi & 13.289 & 1.430 & 9.913 & 16.481 & 3800 \\
\hline
\end{tabular}




\begin{tabular}{llllll|lllllll}
\hline GPA & 0.659 & 0.474 & 0 & 1 & 4940 & GPA & 0.682 & 0.466 & 0 & 1 & 3800 \\
NGPA & 20.380 & 15.439 & 0 & 39 & 4937 & NGPA & 22.183 & 15.864 & 0 & 39 & 3800 \\
CLNGVI & 0.144 & 0.568 & -1.067 & 2.483 & 3420 & CLNGVI & 0.263 & 0.526 & -0.678 & 2.483 & 2622 \\
CLNGVJ & 0.142 & 0.565 & -1.067 & 2.483 & 3420 & CLNGVJ & 0.263 & 0.525 & -0.678 & 2.483 & 2622 \\
RTA & 0.447 & 0.497 & 0 & 1 & 4940 & RTA & 0.468 & 0.499 & 0 & 1 & 3800 \\
gpan & 30.465 & 5.957 & 22 & 39 & 4937 & gpan & 32.200 & 5.654 & 26 & 39 & 3800 \\
Lngvii & 0.165 & 0.624 & -1.067 & 2.483 & 3420 & Lngvii & 0.316 & 0.562 & -0.678 & 2.483 & 2622 \\
Lngvij & 0.165 & 0.624 & -1.067 & 2.483 & 3420 & Lngvij & 0.316 & 0.562 & -0.678 & 2.483 & 2622 \\
\hline
\end{tabular}

Note: a: applicable to LnDIST for trade in services. The only difference between this explanatory for trade in goods and trade in services is the length of time period, which has no effect for the time-invariant variable of bilateral distance.

b:applicable to LnGDPj for trade in services. The summary statistics for LnGDPi and LnGDPj for trade in services are the same.

Table 8 reports pooled regression results for these specifications, with six dependent variables ( Log of GI, GE, SI, SE, FAI and FAE) corresponding to columns (1)-(6) respectively. Focusing on the explanatory variables related to the GPA, the coefficients $\beta_{4}$ for the dummy variable GPA are positive and significant at 1 percent level in columns (1) to (4), which indicate a positive impact for the GPA on bilateral trade in goods and bilateral trade in services via cross-border supply mode.

For trade in services via the commercial presence mode, the dummy variable GPA is not significant for inward foreign affiliates sales. It is dropped in the regression for outward foreign affiliates sales ${ }^{8}$. The interactive variable NGPA has a minor negative coefficient $\beta_{5}$ as expected and is significant in most equations. The coefficients $\beta_{5}$ for NGPA in column (1) and (2) are larger than those in column (3) and (4). This suggests that GPA bilateral trade in goods may be switched more easily between suppliers than bilateral trade in services. The intangibility of services makes the switching costs higher for buyers and bilateral trade in services tends to repeat between current partners.

\footnotetext{
${ }^{8}$ The possible reason lies in the correlation between the dummy variable GPA and the other two interactive variables.
} 
The interactive variable CLNGVI/CLNGVJ has a positive and significant coefficient $\beta_{6}$ in column (3) to (6), but we find no significant coefficient for this explanatory variable for trade in goods. Meanwhile within the two different supply modes for trade in services, exports and imports via foreign affiliate sales are more affected than trade flows involving cross-border supply.

We attribute the difference in the impact of this explanatory variable on trade in goods and in services, as well as the different effects between the two supply modes of trade in services to the high share of services in product composition and high preference for local presence of suppliers by procuring entities in the government procurement market.

Table 8 OLS regression results

\begin{tabular}{|c|c|c|c|c|c|c|}
\hline & \multicolumn{6}{|c|}{ Dependent variables } \\
\hline & $\begin{array}{c}\text { LnGI } \\
(1)\end{array}$ & $\begin{array}{c}\text { LnGE } \\
(2)\end{array}$ & $\begin{array}{c}\text { LnSI } \\
(3)\end{array}$ & $\begin{array}{c}\text { LnSE } \\
(4)\end{array}$ & $\begin{array}{c}\text { LnFAI } \\
\text { (5) }\end{array}$ & $\begin{array}{c}\text { LnFAE } \\
\text { (6) }\end{array}$ \\
\hline \multirow[t]{2}{*}{ LnGDPi } & $1.040 * \star \star$ & $0.843^{\star \star \star}$ & $0.815^{\star \star \star}$ & $0.728^{\star * \star}$ & $0.344^{\star \star \star}$ & 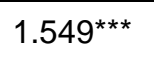 \\
\hline & (0.0133) & $(0.0125)$ & $(0.0142)$ & $(0.0171)$ & $(0.0621)$ & $(0.0943)$ \\
\hline \multirow[t]{2}{*}{ LnGDPj } & $0.846^{\star \star \star}$ & $1.009 * * *$ & $0.804^{\star \star \star}$ & $0.806^{\star \star \star}$ & $0.295^{\star \star \star}$ & $0.778^{\star \star \star}$ \\
\hline & (0.0131) & $(0.0121)$ & $(0.0145)$ & (0.0159) & $(0.0572)$ & $(0.0561)$ \\
\hline \multirow[t]{2}{*}{ LnDIST } & $-0.955^{\star \star \star}$ & $-1.032^{\star \star \star}$ & $-1.003^{\star \star \star}$ & $-0.714^{\star \star \star}$ & $-0.416^{\star \star \star}$ & -0.254 \\
\hline & (0.0308) & $(0.0272)$ & $(0.0329)$ & $(0.0371)$ & $(0.118)$ & (0.299) \\
\hline \multirow[t]{2}{*}{ GPA } & $1.038^{\star \star \star}$ & $1.065^{\star \star \star}$ & $0.337^{\star \star \star}$ & $0.665^{\star \star \star}$ & 0.667 & dropped \\
\hline & $(0.101)$ & $(0.0951)$ & $(0.124)$ & $(0.148)$ & $(0.477)$ & \\
\hline \multirow[t]{2}{*}{ NGPA } & $-0.0330^{\star \star \star}$ & $-0.0311^{\star \star \star}$ & $-0.0177^{\star \star \star}$ & $-0.0191^{\star \star \star}$ & $-0.0500^{\star \star \star}$ & -0.0159 \\
\hline & $(0.00310)$ & $(0.00283)$ & $(0.00354)$ & $(0.00388)$ & $(0.0136)$ & $(0.0201)$ \\
\hline \multirow[t]{2}{*}{ CLNGVI } & -0.00598 & & $0.112^{\star \star \star}$ & & $0.292^{\star \star}$ & \\
\hline & $(0.0317)$ & & $(0.0349)$ & & $(0.147)$ & \\
\hline \multirow[t]{2}{*}{ CLNGVJ } & & 0.00696 & & $0.159 * \star \star$ & & $0.670^{\star \star \star}$ \\
\hline & & $(0.0311)$ & & $(0.0417)$ & & $(0.205)$ \\
\hline \multirow[t]{2}{*}{ RTA } & $0.164^{\star \star}$ & $0.172^{\star \star \star}$ & $0.302^{\star \star \star}$ & $0.312^{\star \star \star}$ & $0.158^{\star \star \star}$ & 0.269 \\
\hline & $(0.0649)$ & $(0.0599)$ & $(0.0706)$ & $(0.0841)$ & $(0.274)$ & $(0.689)$ \\
\hline \multirow[t]{2}{*}{ Constant } & $-9.818^{\star \star *}$ & $-8.868^{\star \star \star}$ & $-6.648^{\star \star \star}$ & $-8.311^{\star \star *}$ & 2.056 & $-21.13^{\star \star \star}$ \\
\hline & $(0.325)$ & $(0.296)$ & $(0.394)$ & $(0.484)$ & (1.530) & (3.386) \\
\hline Observations & 3320 & 3318 & 2115 & 1822 & 1,099 & 528 \\
\hline R-squared & 0.843 & 0.854 & 0.815 & 0.752 & 0.235 & 0.580 \\
\hline
\end{tabular}

Note: *,**and ${ }^{* * *}$ indicate statistical significance at $90 \%, 95 \%$ and $99 \%$ level, respectively. 
Robust standard errors in parentheses.

All the traditional gravity control variables, such as the log of GDP of importers and exporters and the log of distance are of the right sign and statistically significant, except that distance and RTA are not significant in column (6) for FAE. Generally, the magnitudes of the coefficients are also in line with previous literature. Distance has more negative effects on trade in goods than on trade in services regardless of the different supply modes of services, while RTAs are more important for trade in services than trade in goods. This indicates the relative importance of transportation cost for trade in goods and institutional cost for trade in services.

Table 9 presents results from the regressions for country and time fixed effects models using panel data, with six dependent variables ( Log of GI, GE, SI, SE, FAI and FAE) corresponding to columns (1)-(6). The coefficients of log of GDP of exporter and importer also have correct signs and are statistically significant, consistent with the previous pooled regression results. The log of geographical distance are dropped in the country and time fixed effect regressions since they are time-invariant. Based on statistical significance, the dummy variable RTA only shows a positive impact on service export via cross-border supply and inward foreign affiliate sales.

Focusing on the three explanatory variables used to reflect the impact of the GPA on bilateral trade, the coefficient $\beta_{4}$ for dummy variable GPA is positive and significant at 1 percent level in column (1) to (4), similar to the pooled regression results. These indicate a positive impact of the GPA on bilateral trade in goods and bilateral trade in services via cross-border supply mode. For trade in service via commercial presence mode, $\beta_{4}$ is not significant for inward foreign affiliates sales and is dropped in the regression for outward foreign affiliates sales partly because there are too many empty cells to use fixed effects defined over the sample unit as the choice set. However, the higher $\beta_{4}$ in column (3) and (4) suggests that bilateral trade in services is affected more than 
for bilateral trade in goods by GPA membership.

The interactive variable NGPA has a negative coefficient $\beta_{5}$, and is highly significant in column (1) and (2), while when the dependent variables involves trade in services, regression estimates suggest that the GPA has only a small marginal positive effect on service exports via cross-border supply. We attribute the difference in the sign of the coefficient for NGPA in goods and services to the characteristics of services. This suggests the adverse switching effect on bilateral trade in goods can be ignored when assessing GPA impacts on bilateral trade in services.

Table $9 \quad$ Fixed effects results

\begin{tabular}{|c|c|c|c|c|c|c|}
\hline & \multicolumn{6}{|c|}{ Dependent variables } \\
\hline & $\begin{array}{c}\text { LnGI } \\
(1)\end{array}$ & $\begin{array}{c}\text { LnGE } \\
(2)\end{array}$ & $\begin{array}{c}\text { LnSI } \\
(3)\end{array}$ & $\begin{array}{c}\text { LnSE } \\
(4)\end{array}$ & $\begin{array}{c}\text { LnFAI } \\
(5)\end{array}$ & $\begin{array}{c}\text { LnFAE } \\
(6)\end{array}$ \\
\hline LnGDPi & $\begin{array}{l}0.454^{\star \star \star} \\
(0.0592)\end{array}$ & $\begin{array}{l}0.491^{\star * *} \\
(0.0418)\end{array}$ & $\begin{array}{l}1.115^{\star \star \star} \\
(0.0756)\end{array}$ & $\begin{array}{l}0.680 * \star \star \\
(0.0777)\end{array}$ & $\begin{array}{l}0.506^{\star *} \\
(0.198)\end{array}$ & $\begin{array}{l}1.227^{\star * \star} \\
(0.247)\end{array}$ \\
\hline LnGDPj & $\begin{array}{l}0.526^{\star \star \star} \\
(0.0597)\end{array}$ & $\begin{array}{l}0.558^{\star * *} \\
(0.0415)\end{array}$ & $\begin{array}{l}0.616^{\star * *} \\
(0.0713)\end{array}$ & $\begin{array}{l}0.901^{* * *} \\
(0.0674)\end{array}$ & $\begin{array}{c}0.333^{\star} \\
(0.199)\end{array}$ & $\begin{array}{c}0.757^{\star * *} \\
(0.222)\end{array}$ \\
\hline LnDIST & dropped & dropped & dropped & dropped & dropped & dropped \\
\hline GPA & $\begin{array}{c}0.295^{\star \star \star} \\
(0.114)\end{array}$ & $\begin{array}{l}0.569 \star \star \star \\
(0.0797)\end{array}$ & $\begin{array}{l}0.301^{\star \star} \\
(0.153)\end{array}$ & $\begin{array}{c}0.858^{\star \star \star} \\
(0.158)\end{array}$ & $\begin{array}{c}0.121 \\
(0.489)\end{array}$ & dropped \\
\hline NGPA & $\begin{array}{c}-0.00674^{\star *} \\
(0.00325)\end{array}$ & $\begin{array}{c}-0.00853^{\star * \star} \\
(0.00229)\end{array}$ & $\begin{array}{l}-0.00119 \\
(0.00331)\end{array}$ & $\begin{array}{l}0.0177^{\star \star \star} \\
(0.00451)\end{array}$ & $\begin{array}{r}-0.00458 \\
(0.0105)\end{array}$ & $\begin{array}{r}-0.00605 \\
(0.0261)\end{array}$ \\
\hline CLNGVI & $\begin{array}{c}0.0133 \\
(0.0213)\end{array}$ & & $\begin{array}{l}0.0564^{* * *} \\
(0.0213)\end{array}$ & & $\begin{array}{l}-0.0800 \\
(0.0559)\end{array}$ & \\
\hline CLNGVJ & & $\begin{array}{l}0.00939 \\
(0.0149)\end{array}$ & & $\begin{array}{l}0.0792^{\star \star \star} \\
(0.0208)\end{array}$ & & $\begin{array}{l}0.153^{\star *} \\
(0.0628)\end{array}$ \\
\hline RTA & $\begin{array}{c}0.0390 \\
(0.0541)\end{array}$ & $\begin{array}{c}0.0204 \\
(0.0373)\end{array}$ & $\begin{array}{l}0.00539 \\
(0.0849)\end{array}$ & $\begin{array}{l}0.265^{\star \star \star} \\
(0.0878)\end{array}$ & $\begin{array}{c}0.795^{\star \star \star} \\
(0.290)\end{array}$ & dropped \\
\hline Constant & $\begin{array}{c}-5.634^{\star \star \star} \\
(1.126)\end{array}$ & $\begin{array}{c}-6.829 \star \star \star \\
(0.789)\end{array}$ & $\begin{array}{c}-16.70^{\star \star \star} \\
(1.410)\end{array}$ & $\begin{array}{c}-15.32^{\star \star \star} \\
(1.419)\end{array}$ & $\begin{array}{l}-2.625 \\
(3.825)\end{array}$ & $\begin{array}{c}-18.76^{\star \star \star} \\
(4.528)\end{array}$ \\
\hline $\begin{array}{l}\text { Exporting country } \\
\text { fixed effect }\end{array}$ & Yes & Yes & Yes & Yes & Yes & Yes \\
\hline $\begin{array}{l}\text { Importing country } \\
\text { fixed effect }\end{array}$ & Yes & Yes & Yes & Yes & Yes & Yes \\
\hline Year fixed effect & Yes & Yes & Yes & Yes & Yes & Yes \\
\hline Observations & 3320 & 3318 & 2115 & 1822 & 1,099 & 528 \\
\hline
\end{tabular}




\begin{tabular}{ccccccc}
\hline R-squared & 0.410 & 0.619 & 0.588 & 0.715 & 0.382 & 0.489 \\
\hline Note ***and***
\end{tabular}

Note: ***and*** indicate statistical significance at 90\%, 95\% and 99\% level, respectively.

Robust standard errors in parentheses.

The sign and the statistical significance of the coefficient $\beta_{6}$, for interactive variable CLNGVI /CLNGVJ in Table 9 are almost the same as in the pooled regression, except that the magnitude of coefficients in fixed effects regressions becomes smaller. We find no significant coefficients for this explanatory variable in trade in goods and inward foreign affiliate sales. The positive coefficients in column (3),(4) and(6) indicate that with government procurement values above threshold under the GPA, bilateral trade in services and outward foreign affiliate service sales increase. Due to the high proportion of services possess in the government procurement market, any increase in government procurement value above threshold will be largely attributed to services and in turn stimulate bilateral trade in services.

The net effects of GPA membership, number of the GPA members and the growth rate of government procurement values above bound thresholds for the GPA on bilateral trade flow are reported in Table 10. Except for service imports via foreign affiliate sales, GPA membership is positive factor for bilateral trade between the included OECD countries during the sample period. The coefficients on service imports and exports via cross-border supply mode are higher than for goods imports and exports. This indicates that GPA membership plays more important role in promoting bilateral trade in services than for trade in goods. A possible reason may be that service suppliers gain more potential business opportunities in the government procurement market with non-discriminatory and transparent policies than manufacturing suppliers since services account for the majority of the government procurement market for most GPA parties. Results also suggest that exports are influenced more by GPA membership than is the case for 
imports. The value of the coefficient for exports (both trade in goods and services) is almost three times of that of imports.

The number of GPA parties has small marginal negative effects on trade in goods. For service exports it has the opposite sign. Service transactions tend to be repeated and based on reciprocal trust and satisfaction attained in previous deals. Switching costs for either service consumer or service producer are typically higher than for tangible goods consumer and producer. With more members participating in the GPA, bilateral trade in goods between pairs of countries may thus decrease slightly due to switching effects, while existing service trade partners tend to intensify.

The log of index of government procurement values for importers or exporters is a positive determinant of bilateral trade in service, but has no effect on bilateral trade in goods, resulting from the high service share in the growth of government procurement value above threshold under the GPA.

Table 10 The net effect of variables relating to the GPA on bilateral trade flows

\begin{tabular}{|c|c|c|c|c|c|c|}
\hline & \multicolumn{6}{|c|}{ Dependent variables } \\
\hline & $\begin{array}{c}\text { LnGI } \\
(1)\end{array}$ & $\begin{array}{c}\text { LnGE } \\
(2) \\
\end{array}$ & $\begin{array}{c}\text { LnSI } \\
(3)\end{array}$ & $\begin{array}{c}\text { LnSE } \\
(4)\end{array}$ & $\begin{array}{c}\text { LnFAI } \\
(5)\end{array}$ & $\begin{array}{c}\text { LnFAE } \\
(6)\end{array}$ \\
\hline \multicolumn{7}{|c|}{ Fixed effect regression } \\
\hline$\beta_{4}$ & $1.038^{\star \star \star}$ & $1.065^{\star \star \star}$ & $0.337^{\star \star \star}$ & $0.665^{\star \star \star}$ & 0.667 & n.a. \\
\hline$\beta_{5}$ & $-0.0067^{\star \star \star}$ & $-0.0085^{\star \star \star}$ & -0.00119 & $0.0177^{\star \star \star}$ & -0.00458 & -0.00605 \\
\hline$\beta_{6}$ & -0.0133 & 0.00939 & $0.0564^{\star \star \star}$ & $0.0792^{\star \star \star}$ & -0.0800 & $0.153^{\star \star \star}$ \\
\hline Mean of gpan & 30.465 & 30.465 & 32.2 & 32.2 & 32.2 & 32.2 \\
\hline Mean of Lngvii & 0.165 & & 0.316 & & 0.316 & \\
\hline Mean of Lngvij & & 0.165 & & 0.316 & & 0.316 \\
\hline Mean of GPA & 0.659 & 0.659 & 0.682 & 0.682 & 0.682 & 0.682 \\
\hline GPA membership $^{1}$ & 0.0897 & 0.3091 & 0.3188 & 1.4529 & & 0.0483 \\
\hline $\begin{array}{l}\text { Number of the } \\
\text { GPA members2 }\end{array}$ & -0.0044 & -0.0056 & & 0.0121 & & \\
\hline Lngvii $^{3}$ & & & 0.0384 & & & \\
\hline Lngvij $^{3}$ & & & & 0.0540 & & 0.1043 \\
\hline
\end{tabular}

From our results we suggest following policy implications. First, trade in services is likely to 
be fostered by joining the GPA. Country with competitiveness in services will gain from being the GPA party and enlargement of service trade, and may have strong incentive to increase the number of GPA parties and the degree of openness in government procurement market. Second, the high level threshold for the GPA makes foreign affiliate sales the most important supply mode in government service procurement market. Procuring entities will prefer suppliers with local commercial presence to lower supervision costs when open bidding for large procurement contract occurs. This preference for foreign affiliate sales will also deter developing countries from entering the GPA since their suppliers are not bidding with large amounts compared to rivals from developed countries.

Some caveats apply to these results . First the share of government procurement above threshold from foreign suppliers for each GPA party is not included in the explanatory variables due to the unavailability of data in WTO notifications. We use the dummy variable GPA, the interactive variables NGPA and CLNGVI/CLNGVJ to measure the possible impacts the GPA may have on bilateral trade. These proxies need not reflect the real changes in market access in government procurement market. Second, the effective enforcement of non-discriminatory and transparency rules under the GPA is a precondition for the enhanced market access and degree of competition in government procurement market, which generates a two-way interaction between the GPA and bilateral trade in goods and services. On one hand, only when the enhanced market access is achieved will the GPA promote bilateral trade between the GPA parities. On the other hand, market access for the government procurement market is determined by both bilateral and multilateral trade arrangements concerning goods, services and investment. 


\section{Concluding remarks}

In this paper we both discuss the operation of the GPA and the size of markets it covers, and also assess the potential impacts of the GPA on trade among contracting parties using a gravity model. We extend the simple gravity model by adding three explanatory variables relevant to the GPA. These are the GPA membership, the number of the GPA parties and the government procurement value above threshold under the GPA. Our panel data covers 20 OECD countries among which 17 are GPA members and 3 are non-members. The sample period is 1996-2008 for bilateral trade in goods, and 1999-2008 for bilateral trade in services.

Our results suggest that for most parties the GPA has a positive impact on bilateral trade in goods and services, though the magnitude of the impact may varies between trade in goods and services ( with different supply modes). An implication would seem to be that improvements for the GPA should focus on the market access rights for foreign suppliers and should consider the characteristics of services from goods in order to promote international trade. The WTO could also require GPA members to fulfill their obligation in submiting detailed data on government procurement above threshold by origins so as to provide a clear cognition of the openness of the government procurement market under the GPA. 


\section{REFERENCE}

Anderson, J.E. (1979), ‘A Theoretical Foundation for the Gravity Equation,' American Economic Review,69,106-116

Anderson, J.E. and van Wincoop, E. (2003), 'Gravity with Gravitas: A Solution to the Border Puzzle’, American Economic Review, 93:170-192.

Baldwin, R. (1970), Nontariff Distortions of International Trade. Brookings Institution, Washington, DC.

Baldwin, R.and J.D. Richardson, (1972), 'Government purchasing policies, other NTBs, and the international monetary crisis', In English, H.and K. Hay (Eds.) Obstacles to Trade in the Pacific Area. Carleton School of International Affairs, Ottawa.

Branco, F. (1994), 'Favoring domestic firms in procurement contracts', Journal of International Economics, 37, 65-80.

Deardorff, A.V. (1995), 'Determinants of Bilateral Trade: Does Gravity Work in a Neoclassical World?’, NBER Working Papers No. 5377. Massachusetts: NBER.

Eaton, J. and S. Kortum, (2002), ‘Technology, Geography, and Trade.’ Econometrica. 70: 1741-1779.

Egger, P. (2000), 'A Note on the Proper Econometric Specification of the Gravity Equation', Economics Letters, 66, 25-31

Egger, P. (2002), 'An Econometric View on the Estimation of Gravity Models and the Calculation of Trade Potentials’, The World Economy, 25, pp. 297-312.

European Commission, (1988), The Cost of Non-Europe in Public-sector Procurement, Commission of the European Communities, Luxembourg.

European Commission, (1997), The Single Market Review, Subseries III: Dismantling of Barriers, Vol. 2: Public Procurement, Commission of the European Communities, Luxembourg.

European Commission, (2000), 'Measuring the Impact of Public Procurement Policy: First Indicators', Single Market News, March.

Evenett, S. (2002), 'Multilateral Disciplines and Government Procurement', in Hoekman, B.M., A. Mattoo and P. English (Eds): Development, Trade and the WTO: A Handbook, Washington DC : The World Bank, 2002, 417-427. ISBN 0-8213-4997-X.

Evenett, S. and B. Hoekman, (2005), 'Government Procurement: Market Access, Transparency, and Multilateral Trade Rules’, European Journal of Political Economy, 21,163-183.

Feenstra, R.C., J.A. Markusen and A. K. Rose, (2001), 'Using the Gravity Equation to Differentiate Among Alternative Theories of Trade’, Canadian Journal of Economics, 34:430-447. 
Feenstra, R. C. (2003), Advanced International Trade: Theory and Evidence , Princeton, NJ: Princeton University Press

Francois, J. (2001), The Next WTO Round: North-South Stakes in New Market Access

Negotiations, CIES Adelaide and the Tinbergen Institute, CIES: Adelaide, ISBN: 0863964745

Francois, J. F., D. R. Nelson and D. N. Palmeter (1996), 'Public Procurement: A Post- Uruguay Round Perspective’, Centre for Economic Policy Research, Discussion Paper No. 1412, London.

Francois, J. and W. Martin, (2003), 'Formula Approaches for Market Access Negotiations', The World Economy, 26, 1-28.

Gordon, H., S. Rimmer and S. Arrowsmith, (1998), 'The economic impact of the EU regime on public procurement’, The World Economy, 21,159-188.

Grünfeld, L. A. and A. Moxnes, (2003), 'The Intangible Globalization: Explaining the Patterns of International Trade in Services’. Discussion Paper 657. Norwegian Institute of International Affairs, Oslo.

Helpman, E. and P. Krugman (1985), Market Structure and Foreign Trade: Increasing Returns, Imperfect Competition and the International Economy. Cambridge, Mass.: MIT Press.

Hoekman, B. (1997), 'Operation of the Agreement on Government Procurement, 1983-1992', in Hoekman and Mavroidis (eds), Law and Policy in Public Purchasing, , Ann Arbor, Michigan: University of Michigan Press.

Kimura, F. and H. Lee, (2006), 'The Gravity Equation in International Trade in Services', Review of World Economics, 142, 92-121.

Lennon, C. (2006), 'Trade in Services and Trade in Goods: Differences and Complementarities', Paper presented at the 8th Annual Conference of the European Trade Study Group, 7th-9th September, 2006, Vienna

Mattoo, A. (1996), 'The Government Procurement Agreement: Implication of Economic Theory', The World Economy, 19,695-720.

McAfee, R.P. and McMillan, J. (1989), 'Government procurement and international trade’, Journal of International Economics, 26, 291-308.

OECD (2001), Organisation of Economic Cooperation and Development. 'The Size of Government Procurement Markets', Journal of Budgeting, 1(4).

Park, S.-C. (2002), 'Measuring Tariff Equivalents in Cross-Border Trade in Services', Korea Institute for International Economic Policy Working Paper, No. 02-15.

Pöyhönen, P. (1963), ‘A Tentative Model for the Volume of Trade between Countries', Weltwirtschaftliches Archiv,90, 92-100. 
Tinbergen, J. (1962), Shaping the World Economy_-Suggestions for an International Economic Policy, New York: The Twentieth Century Fund.

Trionfetti, F. (2000), 'Discriminatory public procurement and international trade', The World Economy, 23, 57-76.

Trionfetti, F. (2001), ‘Public Procurement, Market Integration, and Income Inequalities’, Review of International Economics, 9, 29-41

Wang, P. (2007), 'Coverage of the WTO’s Agreement on Government Procurement: Challenges of Integrating China and Other Countries with a Large State Sector into the Global Trading System', Journal of International Economic Law, 10, 887-920. 